\title{
Effects of clinoptilolite addition to colostrum on the concentration of serum proteins, minerals, enzyme activities in neonatal calves
} Simona Marc Zarcula ${ }^{1}$, Călin Mircu ${ }^{1}$, Gheorghe Bonca ${ }^{1}$, Danijela Kirovski ${ }^{2}$, Gabriel Otavă ${ }^{1}$, Mirela Ahmadi-Khoie ${ }^{1}$, Camelia Tulcan ${ }^{1 *}$

${ }^{1}$ Faculty of Veterinary Medicine, University of Agricultural Sciences and Veterinary Medicine from Banat, Timişoara, Calea Aradului no 119, România

${ }^{2}$ Faculty of Veterinary Medicine, University of Belgrade, Bulevar Oslobodjenja no 18, Serbia *Corresponding author: cameliatulcan@usab-tm.ro

\begin{abstract}
The objective of our research was to determine the effects of colostrum supplementation with clinoptilolite on concentrations of serum proteins, minerals and enzyme activities in newborn calves. Twenty newborn calves that were divided into control group $(n=10)$ which received colostrum and experimental group $(n=10)$ that received colostrum with $0.5 \%$ clinoptilolite added in the first three colostrum meals were studied. Blood samples were collected from jugular vein in vacutainer tubes from all calves prior to colostrum intake and after that, at 24 and $48 \mathrm{~h}$ after birth. Samples were analyzed for total protein, albumin, a1-globulin, a2-globulin, B-globulin, $\gamma$-globulin, calcium, phosphorus, magnesium, iron, gamma glutamyltransferase, alanine aminotransferase, aspartate aminotransferase and alkaline phosphatase. Clinoptilolite supplementation had significant effect $(p<0.0006)$ on serum iron concentrations in experimental $(27.64 \pm 3.78 \mu \mathrm{mol} / \mathrm{l}) \mathrm{vs}$ control group $(8.93 \pm 1.26 \mu \mathrm{mol} / \mathrm{l})$ after $48 \mathrm{~h}$. GGT values were also significantly higher $(\mathrm{p}<0.04)$ in $\mathrm{E}(163.60 \pm 26.67 \mathrm{U} / \mathrm{l})$ than in $C$ group $(84.01 \pm 19.77 \mathrm{U} / \mathrm{l})$ at $48 \mathrm{~h}$ after parturition. Other parameters analyzed were unaffected by clinoptilolite treatment. Obtained data revealed that colostrum supplemented with clinoptilolite had positive effects on some mineral parameters.
\end{abstract}

\section{Indexing terms/Keywords}

Clinoptilolite; Calves; Enzyme activities; Minerals; Serum proteins

\section{Academic Discipline And Sub-Disciplines}

Veterinary Medicine, Biochemistry

\section{SUBJECT CLASSIFICATION}

Medical Subject Classification

\section{TYPE (METHOD/APPROACH)}

Experimental study

\section{Council for Innovative Research}

\author{
Peer Review Research Publishing System
}

Journal: Journal of Advances in Chemistry

Vol. 10, No. 2

editorjaconline@gmail.com 


\section{INTRODUCTION}

Colostral period represents an important moment for the newborns; especially in ruminants. In these species acquiring passive immunity is achieved exclusively through ingestion and absorption of adequate amounts of colostral immunoglobulins (lg)[21]. Starting a good protection against neonatal diseases depends on how this period is managed. Due to many factors that affect the level of colostrum immunoglobulins absorbed, the incidence of passive immunity failure is still high in young ruminants, clinical seen in high incidence of neonatal morbidity and mortality, with reducing the average daily gain and increased frequencies of treatments and economic costs [2, 6, 21].

One natural method for reducing the failure passive transfer (FPT) by improving the absorption of Ig can be done with clinoptilolite, a natural zeolite [3, 4, 19]. Zeolites are crystalline, hydrated aluminosilicates of alkali and alkaline earth cations, having three-dimensional structures capable of trapping molecules of proper dimensions for further release or elimination [10,11]. Biological effects of zeolites make use of one or more of their properties, such as ion exchange capacity, adsorption and related molecular sieve $[10,11]$. Due to their unique properties, zeolites are used in a wide range of biological processes where they have beneficial effects both in veterinary and human medicine [10, 11, 12]. Enhancement of passive immunity in newborn calves leads to other positive effects like reducing the incidence of diarrhea and higher average weight $[17,18]$.

Effects of zeolites in animal nutrition could be influenced by different length of administration, different type, particles size and purity of the zeolitic material and by different physiological processes involved in digestion of feed in young and adult animals $[9,12]$.

Literature data regarding positive effects of zeolite supplimentation on passive immunity $[3,4,17]$ and on biochemical parameters $[9,18,19]$ in newborns calves exist, with zeolites used in different doses and for different time interval, but not in higher quantity of colostrum. From this reason our objective was to determine the effects of short term clinoptilolite added in colostrum (3 I) in Holstein calves on the level of resorption of colostrum immunoglobulin, values of some minerals and enzymatic parameters.

\section{MATERIALS AND METHODS}

The study was carried out on 20 newborn Holstein calves in a farm with 540 dairy cows, in Western part of Romania. All procedures used in animal experiments were in compliance with local ethics committee. Calves were managed according to the farm procedures. Briefly, calves were separated from the dams within 10-20 min after parturition in individual pens, without nursing. They were fed nipple bottle $2 \mathrm{~h}$ after birth with $3 \mathrm{I}$ of mother's colostrum, at $12 \mathrm{~h}$ interval, during the first 5 days postpartum. After colostrum period, calves received herd milk. From first week of life, calves were offered high quality starter and water ad libitum. The individual pens were cleaned daily. For experimental design, the calves were assigned in two groups based on the birth order. Control $(C)$ group $(n=10)$ were fed nipple bottle $2 \mathrm{~h}$ after birth with colostrum and experimental (E) group $(n=10)$ with colostrum containing $0.5 \%$ of clinoptilolite, in the first 3 meals. The blood samples were collected from jugular vein in vacutainer tubes prior to colostrum intake, at 24 and $48 \mathrm{~h}$ after giving first colostrum. Serum was obtained after centrifugation the samples at $3000 \mathrm{rpm}$ for 5 minutes and stored at $-20^{\circ} \mathrm{C}$ until analysis.

Colostrum IgG were analyzed by radial immunodifussion method (INEP ZEMUN, Belgrad, Serbia) and concentrations of fat, protein, lactose, solid non-fat extract were determinated with automatic milkanalyser (LactoScan, Delta Intrumentes).

The commercial product used in experiment was Min-a-Zel S, from PATENTKOMERC, Belgrad, Serbia. The composition of clinoptilolite was $64.21 \% \mathrm{SiO}_{2} ; 11.48 \% \mathrm{Al}_{2} \mathrm{O}_{3} ; 0.88 \% \mathrm{Fe}_{2} \mathrm{O}_{3} ; 0.25 \% \mathrm{TiO}_{2} ; 0.03 \% \mathrm{MnO} ; 4.55 \% \mathrm{CaO} ; 1.45 \% \mathrm{MgO} ; 1.71 \%$ $\mathrm{Na}_{2} \mathrm{O} ; 1.29 \% \mathrm{~K}_{2} \mathrm{O}$ and $14.00 \%$ L.O.I. (Ioss on ignition). The chemical analysis of the product was determined at Institute for the Application of Nuclear Energy (ITNMS), Serbia.

The concentrations of total protein (TP), calcium (Ca), magnesium (Mg), phosphorus (P), iron (Fe) and activities of aspartate aminotransferase (AST), alanine aminotransferase (ALT), gamma glutamyltransferase (GGT) and alkaline phosphatase (ALP) in serum samples were determinated with commercially available kits (Hospitex Diagnostics, Italy) using biochemical automatically analyzer (EOS Bravo Forte, Hospitex, Italy). HD calibrator serum, HD normal serum and QC serum (Hospitex, Italy) was used for controlling measurement accuracy. The automated system was regularly monitored for accuracy and precision in accordance with "Good laboratory practice" guidelines.

Protein fraction (albumin, a1-globulin, a2-globulin, B-globulin and $\mathrm{\gamma}$-globulin) were analyzed by electrophoresis on cellulose acetate with kits for determining serum protein (Interlab, Italy) with Genio electrophoresis device.

Serum concentrations of protein fraction $(\mathrm{g} / \mathrm{l})$ were obtained according to relation:

$$
\text { Concentration of protein fraction }(\mathrm{g} / \mathrm{l})=\frac{\text { total protein } \cdot \text { protein fraction }}{100}
$$

Albumin/globulins ratio $(\mathrm{A} / \mathrm{G})$ was obtain according to relation:

$$
\mathrm{A} / \mathrm{G} \text { ratio }=\frac{\text { albumin concentrat ion }}{\sum \text { globulin concentrat ions }}
$$


The apparent efficiency of $\lg G$ absorption (AEA) was calculated according to the next equation for individual calves at 24 hours after parturition, where plasmatic volume was expressed as $9.1 \%$ of body weight (16):

$$
\operatorname{AEA}(\%)=\frac{\text { serum IgG concentrat ion X plasmatic volume }}{\operatorname{IgG} \text { consumed }} \cdot 100
$$

Values are expressed as means with standard error. One way analysis of variance (ANOVA) was used to test for statistically differences $(p<0.05)$ between the groups of calves and inside the group.

\section{RESULTS}

The mean values of total protein, globulin fractions, mineral and enzymatic parameters in blood serum of calves at parturition and after birth at different intervals are shown in Table 1 and 2.

Table 1. Total protein and protein fractions concentrations in blood serum of calves at different time interval

\begin{tabular}{|c|c|c|c|c|}
\hline Parameters & Group & At parturition & $24 \mathrm{~h}$ & $48 \mathrm{~h}$ \\
\hline \multirow{2}{*}{ Total protein $(\mathrm{g} / \mathrm{l})$} & $\mathrm{C}$ & $46.84 \pm 1.72$ & $67.97 \pm 5.11$ & $71.21 \pm 5.02$ \\
\cline { 2 - 5 } & $\mathrm{E}$ & $50.81 \pm 1.23$ & $72.07 \pm 5.59$ & $70.65 \pm 4.35$ \\
\hline \multirow{2}{*}{ Albumin $(\mathrm{g} / \mathrm{l})$} & $\mathrm{C}$ & $34.55 \pm 1.45$ & $37.27 \pm 2.45$ & $36.72 \pm 2.28$ \\
\cline { 2 - 5 } & $\mathrm{E}$ & $35.70 \pm 1.76$ & $40.68 \pm 1.67$ & $39.39 \pm 2.16$ \\
\hline \multirow{2}{*}{ a1-globulin $(\mathrm{g} / \mathrm{l})$} & $\mathrm{C}$ & $4.60 \pm 1.76$ & $6.49 \pm 1.25$ & $6.76 \pm 1.74$ \\
\cline { 2 - 5 } & $\mathrm{E}$ & $4.79 \pm 1.16$ & $4.91 \pm 1.13$ & $5.71 \pm 1.14$ \\
\hline \multirow{2}{*}{ a2-globulin $(\mathrm{g} / \mathrm{l})$} & $\mathrm{C}$ & $2.35 \pm 0.69$ & $5.87 \pm 1.32$ & $6.06 \pm 1.49$ \\
\cline { 2 - 5 } & $\mathrm{E}$ & $4.83 \pm 1.45$ & $8.12 \pm 2.20$ & $7.01 \pm 1.47$ \\
\hline \multirow{2}{*}{ B-globulin $(\mathrm{g} / \mathrm{l})$} & $\mathrm{C}$ & $4.14 \pm 0.68$ & $5.68 \pm 0.64$ & $6.57 \pm 1.16$ \\
\cline { 2 - 5 } & $\mathrm{E}$ & $4.40 \pm 0.55$ & $5.36 \pm 0.51$ & $6.12 \pm 0.49$ \\
\hline \multirow{2}{*}{ Y -globulin $(\mathrm{g} / \mathrm{l})$} & $\mathrm{C}$ & $1.21 \pm 0.26$ & $12.79 \pm 1.78$ & $15.44 \pm 1.85$ \\
\cline { 2 - 5 } & $\mathrm{E}$ & $1.07 \pm 0.30$ & $13.00 \pm 2.28$ & $12.42 \pm 1.37$ \\
\hline \multirow{2}{*}{ A/G } & $\mathrm{C}$ & $3.19 \pm 0.41$ & $1.26 \pm 0.10$ & $1.20 \pm 0.18$ \\
\cline { 2 - 5 } & $\mathrm{E}$ & $2.66 \pm 0.34$ & $1.53 \pm 0.22$ & $1.39 \pm 0.14$ \\
\hline
\end{tabular}

Significant differences $(p<0.05)$ inside the group: vs parturition 
Table 2. The concentration of minerals and enzymatic activites in blood serum of calves

\begin{tabular}{|c|c|c|c|c|}
\hline Parameters & Group & At parturition & $24 h$ & $48 \mathrm{~h}$ \\
\hline \multirow{2}{*}{$\mathrm{Ca}(\mathrm{mmol} / \mathrm{l})$} & $\mathrm{C}$ & $3.38 \pm 0.26$ & $3.40 \pm 0.08$ & $3.50 \pm 0.13$ \\
\hline & $E$ & $4.13 \pm 0.17^{\mathrm{a}}$ & $3.92 \pm 0.17^{b}$ & $4.19 \pm 0.13^{c}$ \\
\hline \multirow{2}{*}{$\mathrm{P}(\mathrm{mmol} / \mathrm{l})$} & $\mathrm{C}$ & $2.44 \pm 0.52$ & $2.61 \pm 0.29$ & $3.32 \pm 0.54$ \\
\hline & $E$ & $2.65 \pm 0.48$ & $3.02 \pm 0.53$ & $3.32 \pm 0.62$ \\
\hline \multirow{2}{*}{$\mathrm{Mg}(\mathrm{mmol} / \mathrm{l})$} & C & $1.34 \pm 0.08$ & $1.33 \pm 0.08$ & $1.38 \pm 0.14$ \\
\hline & $E$ & $1.48 \pm 0.07$ & $1.42 \pm 0.07$ & $1.34 \pm 0.05$ \\
\hline \multirow{2}{*}{$\mathrm{Fe}(\mu \mathrm{mol} / \mathrm{l})$} & $\mathrm{C}$ & $13.91 \pm 3.16$ & $14.24 \pm 2.24$ & $8.93 \pm 1.26$ \\
\hline & $E$ & $12.55 \pm 2.48$ & $20.03 \pm 3.12$ & $27.64 \pm 3.78^{\circ \mathrm{C}}$ \\
\hline \multirow{2}{*}{ GGT (U/I) } & $\mathrm{C}$ & $10.95 \pm 3.93$ & $82.91 \pm 10.46$ & $84.01 \pm 19.77$ \\
\hline & $E$ & $12.84 \pm 4.94$ & $126.57 \pm 37.78$ & $163.60 \pm 26.67^{\circ \mathrm{C}}$ \\
\hline \multirow{2}{*}{$\operatorname{ALP}(\mathrm{U} / \mathrm{I})$} & $\mathrm{C}$ & $463.70 \pm 79.78$ & $789.82 \pm 109.10$ & $642.87 \pm 119.47$ \\
\hline & $E$ & $473.69 \pm 63.89$ & $729.96 \pm 90.25$ & $692.30 \pm 67.74$ \\
\hline \multirow{2}{*}{ AST (U/I) } & $\mathrm{C}$ & $42.40 \pm 14.22$ & $83.53 \pm 13.32$ & $74.01 \pm 9.44$ \\
\hline & $E$ & $55.85 \pm 10.63$ & $98.97 \pm 7.58$ & $88.90 \pm 26.10$ \\
\hline \multirow{2}{*}{ ALT (U/I) } & $\mathrm{C}$ & $5.67 \pm 1.41$ & $13.66 \pm 4.19$ & $8.65 \pm 2.63$ \\
\hline & $\mathrm{E}$ & $5.04 \pm 0.91$ & $7.11 \pm 1.88$ & $8.42 \pm 2.39$ \\
\hline
\end{tabular}

Group had significant effect on the values of GGT, Ca and Fe (Table 2). These values were significantly higher in group E than $C$ group ( $p<0.04$ for GGT; $p<0.002$ for $\mathrm{Ca}$ and $p<0.0006$ for $\mathrm{Fe}$ ) at $48 \mathrm{~h}$ postpartum. GGT level was significantly increased in group $E$ at 48 hours $(E / C:+94.73 \%, p<0.04)$. Inside the groups from parturition till $48 \mathrm{~h}$ postpartum $\mathrm{GGT}$ increased significantly both in control group and in experimental group: 7.67 times in group $C(p<0.009)$ and 12.74 times in group $\mathrm{E}(\mathrm{p}<0.008)$. The difference between groups regarding $\mathrm{Ca}$ values was not relevant for discussion because a significant difference between groups was also found at parturition $(p<0.02)$. The differences between groups for ALP were: at parturition $\mathrm{E} / \mathrm{M}:+2.15 \%, \mathrm{p}<0.92$; at $24 \mathrm{~h} \mathrm{E} / \mathrm{M}:-7.57 \%, \mathrm{p}<0.67$; at 48 hours $\mathrm{E} / \mathrm{M}:+7.68 \%, \mathrm{p}<0.71$. At $48 \mathrm{~h}$ postpartum albumin/globulin ratio $(\mathrm{A} / \mathrm{G})$ decreased in both group with $60.50 \%(\mathrm{p}<0.0003)$ in $\mathrm{C}$ group and with $42.48 \%$ $(p<0.01)$ in group $E$, with no differences between groups.

The chemical composition of colostrum administrated to calves from both groups was similar for all parameters: (C group: $64.78 \pm 1.45 \mathrm{~g} / \mathrm{lgG}$; $8.46 \pm 1.17 \%$ fat; $17.94 \pm 1.14 \%$ protein; $2.23 \pm 0.19 \%$ lactose and $28.65 \pm 2.15 \%$ solid non-fat; E group: $62.55 \pm 3.86 \mathrm{~g} / \mathrm{lgG} ; 7.52 \pm 1.12 \%$ fat; $17.49 \pm 1.46 \%$ protein; $2.31 \pm 0.12 \%$ lactose and $27.34 \pm 2.06 \%$ solid non-fat).

\section{DISCUSSION}

Different studies on calves fed with colostrum supplemented with clinoptilolite gave positive results on lg levels and on reducing diarrhea. According to Fratrić et al. [3] the IgG concentration during the first $48 \mathrm{~h}$ of life in newborn calves that received $5 \mathrm{~g} / \mathrm{l}$ clinoptilolite in $0.75 \mathrm{l} / 1.5 \mathrm{l}$ colostrum at $12 \mathrm{~h}$ intervals was up to $40 \%$ higher than in control groups. In stead Sadeghi et al. [17] did not achieve a significant increase in passive immunity to calves that received clinoptilolite at various concentrations for 45 days $(0.5 / 1 / 1.5 / 2 \mathrm{~g}$ clinoptilolite $/ \mathrm{kg}$ body weight), but clinically they reported fewer cases of diarrhea in the group that received clinoptilolite $(1 \mathrm{~g} / \mathrm{kg}$ body weight). In our study clinoptilolite supplementation had no significant effect on y globulin fraction, but increased significantly in both groups after colostrum administration, being more than 10 $\mathrm{g} / \mathrm{l}$ at $24 \mathrm{~h}$; the level that is generally considered to be adequate for succesful transfer of passive immunity [21]. A reason of these results could be the high quantity of colostrum administrated. It is known that Ig absorption efficiency is inversely proportional to the amount of $\mathrm{g}$ in colostrum, suggesting that there is a peak saturation of the transport mechanism for macromolecules in the intestine [16]. Apparent efficiency of absorption (AEA), the efficiency with which Ig are absorbed, was calculated for understanding the dynamics of $\mathrm{lg}$ absorption. The AEA in calves from both groups at $24 \mathrm{~h}$ was low $(24.02 \pm 3.61 \%$ in $\mathrm{C}$ group and $25.89 \pm 3.78 \%$ in $E$ group), this could be due to high quantity of colostrum fed that may not improve absorption. 
Albumin, $\alpha 1, \alpha 2$ globulin and $\beta$ globulin fractions recorded variations with no significant differences between groups. Different from our results, Mohri et al. (2007) observed increased serum albumin levels following supplementation with $2 \%$ clinoptilolite, probably due to length of administration (14 d)[8].

The effects of zeolites on serum minerals in dairy cows, sows/gilts, mice have been studied [7, 13, 20]. In agreement with the results of Mohri et al. [9] and different from Step et al. [19], our study suggested significant increase of iron level at 48h $(p<0.0006)$ in calves that received $0.5 \%$ clinoptilolite in colostrum. A possible explanation could be that in duodenum and in anterior part of jejunum, where iron absorption take place, clinoptilolite influence iron absorption due to ion exchange properties; altering in this way the $\mathrm{pH}$ or by reducing intestinal transit of digesta, that could lead to a better utilization of nutrients $[7,12,15]$. It is known that low intestinal motility and acid pH promotes iron absorption and that in the bovine neonate the $\mathrm{pH}$ of the whole intestinal content ranges from 5.5 to 6.5 , also the motility of the gastrointestinal tract become well organized only after first 2-3 days of postnatal life [5, 15]. This benefice could be important in preventing iron deficiency anemia ( $\mathrm{Fe}<14.32 \mu \mathrm{mol} / \mathrm{l})$ especially in veal calves fed exclusively with milk [15]

Other important parameters for monitoring the physiology of newborns are enzymes. Increased GGT values after colostrum ingestion in this experiment underlines the useful of this biochemical parameter in predicting the efficiency of passive transfer in newborns, due to its absorption from colostrum. A limit value of $<50 \mathrm{U} / \mathrm{l} \mathrm{GGT}$ in the first 2 weeks of life had been established as predicting failure of passive transfer $\left(<10 \mathrm{~g} / \mathrm{lg} \mathrm{Ig}_{1}\right)$ [14]. ALP activity was higher before consuming colostrum and increased significantly in all calves at 24 and $48 \mathrm{~h}$ postnatal. Factors responsible of this high activity of ALP in the first month of life are: intense digestion that take place in the gut after the consumption of colostrum rich in nutrients which can stimulates growing the activity of intestinal ALP; intense activity of osteoblasts in calves during the first month of life, which implies that existence of bone izoenzimatic form in greater quantity (B-ALP, bone alkaline phosphatase)[1]. Enzyme activities AST and ALT in calves who received clinoptilolite added in colostrum were not significantly different from control group which means that clinoptilolite added in colostrum has no influence on parenchymatous organs; similar results to previous studies $[7,18]$. Most biochemical parameters in newborn animals are different from those of adults due to their special needs for adapting to the new environment and due to colostrum consumption.

\section{CONCLUSION}

The results of our study show that short-time supplementation with clinoptilolite in high quantity of colostrum increased the iron level in the first 2 days after birth, did not improve absorption of immunoglobulins from colostrum probably due to high quantity of colostrum and had no negative effects on other biochemical parameters; which means that morphofunctional processes that take place in the newborns, necessary for adapting to the new environment, were not affecting.

\section{ACKNOWLEDGEMENT}

We would like to thank PATENTKOMERC, Serbia for providing us the Min-a-Zel S product.

\section{REFERENCES}

[1] Boyd J.W. 1989. Serum Enzyme changes in newborn calves fed colostrum. Vet Clin Pathol, 18, 47-51.

[2] Chigerwe M., Tyler J.W., Summers M.K., Middleton J.R., Schultz L.G., Nagy D.W. 2009. Evaluation of factors affecting serum IgG concentrations in bottle-fed calves. J Am Vet Assoc, 234, 785-789.

[3] Fratrić N., Stojić V., Janković D., Šamanc H., Gvozdić D. 2005. The effect of a clinoptilolit based mineral adsorber on concentrations of immunoglobulin $\mathrm{G}$ in the serum of newborn calves fed different amounts of colostrum. Acta Vet, 55, 11-21.

[4] Fratrić N., Stojić V., Rajcić S., Radojičić B. 2007. The effect of mineral adsorbent in calf diet colostrum on the levels of serum immunoglobulin G, protein and glucose. Acta Vet, 57, 169-180.

[5] Guilloteau P., Zabielski R., Blum J.W. 2009. Gastrointestinal tract and digestion in the young ruminat: ontogenesis, adaptations, consequences and manipulations. J Physiol Pharmacol, 60, 37-46

[6] Jaster E.H. 2005. Evaluation of quality, quantity and timing of colostrum feeding on immunoglobulin $\mathrm{G}_{1}$ absorption in Jersey calves. J Dairy Sci, 88, 296-302.

[7] Martin-Kleiner I., Flegar-Meštric Z., Zadro R., Breljak D., Stanović Janda S., Stojković R., Marušic M., Radačic M., Boranić M. 2001. The effect of the zeolite clinoptilolite on serum chemistry and hematopoiesis in mice. Food Chem Toxicol, 39, 717-727.

[8] Mohri M., Seifi H.A., Daraei F. 2007. Effects of short-term supplementation of clinoptilolite in colostrum and milk on hematology, serum proteins, performance, and health in neonatal dairy calves. Food Chem Toxicol, 46, 2112-2117.

[9] Mohri M., Seifi H.A., Maleki M. 2008. Effects of short-term supplementation of clinoptilolite in colostrum and milk on the concentration of some serum minerals in neonatal dairy calves. Bio Trace Elem Res, 123, 116-123.

[10] Mumpton F.A., Fishman P.H. 1977. The application of natural zeolites in animal science and aquaculture. J Anim Sci, 45, 1188-1203. 
[11] Mumpton F.A. 1999. La roca magica: Uses of natural zeolites in agriculture and industry. Proc Nat Acad Sci, 96, 3463-3470.

[12] Papaioannou D., Katsoulos P.D., Panousis N., Karatzias H. 2005. The rol of natural and synthetic zeolites as feed additives on the prevention and/or the treatament of certain farm animal diseases: a review. Micropor Mesopor Mat, 84, 161-170.

[13] Papaioannou D.S., Kyriakis S.C., Papasteriadis A., Roumbies N., Yannakopoulos A., Alexopoulos C. 2002. A field study on the effect of in-feed inclusion of a natural zeolite (clinoptilolite) on health status and performance of sows/gilts and their litters. Res Vet Sci, 72, 51-59.

[14] Parish S.M., Tyler J.W., Besser T.E., Gay C.C., Kryzenberg D. 1997. Prediction of Serum IgG1 Concentration in Holstein Calves Using Serum Gamma Glutamyltransferase Activity. J Vet Intern Med, 11, 344-347.

[15] Pârvu G. 1992. Nutritional-metabolic surveillance of animals. Ceres Ed, Bucharest, pp. 235-300.

[16] Quigley J. 2002. Passive Immunity in Newborn Calves. Adv Dairy Tech, 14, 273-292.

[17] Sadeghi A., Shawrang P. 2008. Effects of natural zeolite clinoptilolite on passive immunity and diarrhea in newborn calves. Livest Sci, 113, 307-310.

[18] Šamanc H., Kirovski D., Adamović M., Vujanać I., Fratrić N., Prodanović R. 2008. Effects of natural zeolite on body weight, weight gain, hematology and biochemical blood parameters in calves. Vet Glasnik, 62, 153-166.

[19] Step D.S., Litherland N.B., Burciaga-Roble O., Breshears M., Krehbiel C.R., Confer A.W., Fulton R.W., Morgan G.L., Thornsberry M., Fassig S.M. 2008. Clinical observations, biochemical data and postmortem and histopathologic findings in young dairy calves fed zeolite clinoptilolite binder combined with milk replacer. Am J Vet Res, 69, 15871594.

[20] Thilsing-Hansen T., Jorgensen R.J., Enemark J.M.D., larsen T. 2002. The effect of zeolite A supplementation in the dry period of periparturient calcium, phosphorus and magnesium homeostasis. J Dairy Sci, 85, 1855-1862.

[21] Weaver D.M., Tyler J.W., Van Metre D.C., Hostetler D.E., Barrington G.M. 2000. Passive transfer of colostral immunoglobulins in calves-review. J Vet Intern Med, 14, 669-577.

\section{Author' biography with Photo}

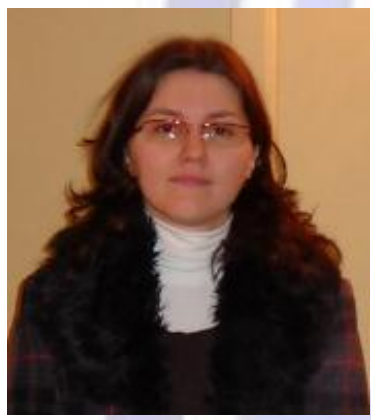

DVM. PhD. MARC ZARCULA SIMONA, 31 years old

Current position: researcher at University of Agricultural Sciences and Veterinary Medicine from Banat Timisoara

\section{Professional experience}

2011-2013: Postdoctoral researcher, in the project „Postdoctoral School of Agriculture and Veterinary Medicine" POSDRU89/1.5/S/62371, with the project "In vitro fertilization in bovine species". Traineeship made during three months in the "In vitro fertilization" laboratory, from Besamungsverein, Neustadt a.d. Aisch, Germany. Compentence in achivement in vitro fertilization in bovine species: methods in recovering bovine oocytes, maturation and fertilization of oocytes, preparing of bull semen for oocytes fertilization, cultivation and cryoconservation of bovine embryos.

2010-2013: analyst in the biochemical laboratory from the Platform Laboratories of Interdisciplinary training and research "Organic farming and sustainable food security" at the University of Agricultural Sciences and Veterinary Medicine Timisoara, Romania.

2007-2010: PhD-student, Faculty of Veterinary Medicine from Timisoara, thesis title „Research on the immune status in newborn calves”, PhD in Veterinary Medicine, coordinator Prof.Dr.h.c. Horia Cernescu

2001-2007: student, Faculty of Veterinary Medicine from Timisoara, disertation paper „Consequences of exposure to aluminium sulfate on semen quality biomarkers in rat”, coordinator Prof.Dr.h.c. Alexandra Trif.

Scientific activity: published 31 scientific works, in 9 like first author.

\section{List of the most significant achievements:}

1. Simona Marc Zarcula, Camelia Tulcan, Mircu Călin, Godja Gabriel and Gheorghe Bonca, Ovum pick-up (OPU) utilisation in cattle, teoretical aspects, Lucrările celui de al XV- lea Simpozion Internaţional Tinerii şi Cercetarea Multidisciplinară, 14-15 noiembrie 2013, Timişoara, România, pp. 133-138. 
2. Simona Marc Zarcula, Camelia Tulcan, Danijela Kirovski, H. Samanc, C. Mircu, GH. Bonca, G. Otavă, D. Chirilă, $\mathrm{H}$. Cernescu, Effects of short term addition of clinoptilolite to colostrum on some biochemical parameters in newborn calves, Lucr. St. Med. Vet, Vol XLVI (3), 167-172, (2013).

3. Camelia Tulcan, Violeta Igna, Mirela Ahmadi, Simona Zarcula, Marilena Motoc, Claudia Borza, Quantitative Analysis of Superoxide Ions, Hydroperoxide and Lipoperoxidation Products in Characterizationof Fresh Organic Fluid Quality", REV. CHIM., vol.64, no.2, pp. 195-197, 2013.

4. Simona Marc Zarcula, Horia Cernescu, Gabriel Godja, Violeta Igna, Effects of recovering bovine oocyte methods on quantity and quality of cumulus-oocyte complexes, The 1 st Virtual International Conference „Advanced Research in Scientific Areas", Slovak Republica, 3-7.12.2012, (http://www.arsa-conf.com/ )

5. V. Ardelean, Violeta Igna, Simona Marc Zarcula, GH. Bonca, C. Mircu, G. Otavă, H. Cernescu, G. Godja, M.G. Muresan, A. Ardelean, Registered constants of mobility parameters after thawing of cryopreserved semen in Holstein Friesian breed bulls, Lucr. St. Med. Vet, Vol XLVI, 2013.

Member of Scientific Societies

Association for Multidisciplinary Research in the West Zone of Romania (www.acmv.ro)

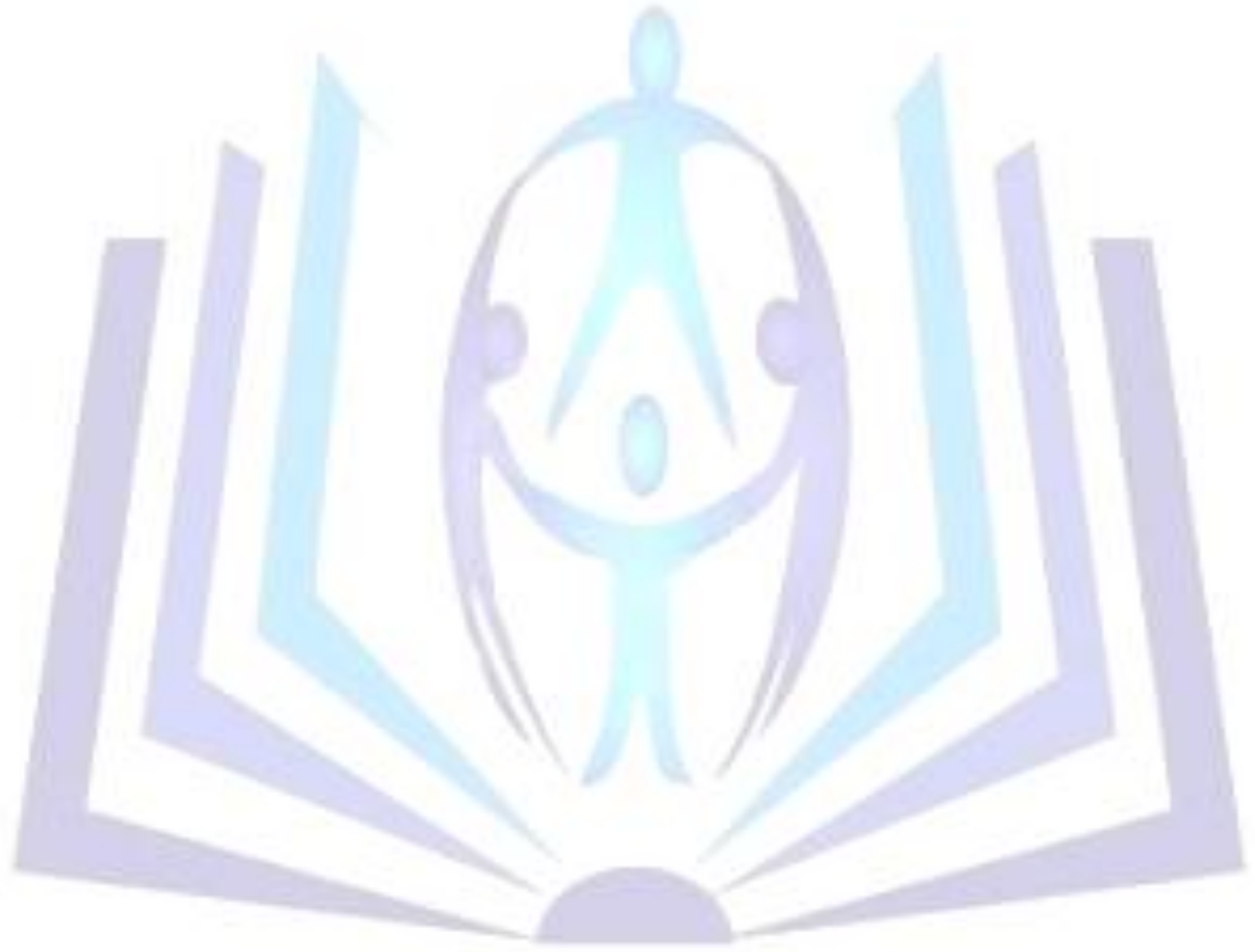

